\title{
New distinctive miospore species from the Namurian of the Upper Silesia Coal Basin, Poland
}

\author{
MARZENA OLIWKIEWICZ-MIKLASIŃSKA \\ Institute of Geological Sciences, Polish Academy of Sciences, Kraków Research Centre,1 Senacka Street, 31-002 Kraków, Poland.
}

\begin{abstract}
Three new miospore species, Pilosisporites aleksandrae, Neoraistrickia crinita and Pteroretis obliquus are described from the Namurian of the Upper Silesia Coal Basin. The first two species appear to be stratigraphically restricted to the Arnsbergian-Marsdenian stages. Pilosisporites aleksandrae occurs in miospore assemblages representing the west European miospore zones Stenozonotriletes triangulus-Rotaspora knoxi (TK), Kraeuselisporites ornatus-Lycospora subtriquetra (SO) and Crassispora kosankei-Grumosisporites varioreticulatus (KV), while Neoraistrickia crinitaoccurs in the SO and KV zones. Pteroretis obliquus is recorded from the upper part of the SO Zone and KV Zone and has a slightly shorter stratigraphical range, probably Chokierian-Marsdenian. J. Micropalaeontol. 20(2): 169-177, December 2001.
\end{abstract}

\section{INTRODUCTION}

The new miospore taxa described here were found in samples collected from the transitional part of the Upper Carboniferous profile between paralic and continental deposits, in the vicinity of Rybnik (western part of the Upper Silesia Coal Basin; Fig. 1). In the informal lithostratigraphic division (Kotas, 1995; Fig. 2), the examined samples represent the Poruba Beds of the so-called Paralic Series, the Jejkowice Beds, and the Saddle Beds of the so-called Upper Silesia Sandstone Series. Ninety samples were collected from three boreholes: Jejkowice IG 1, Paruszowiec 13 and Paruszowiec 25 (Fig. 3). The frequency of sampling depended on lithology. The Poruba Beds are arenaceous deposits with numerous mudstone intercalations and coal seams. The Jejkowice Beds are coarse clastic sediments with rare

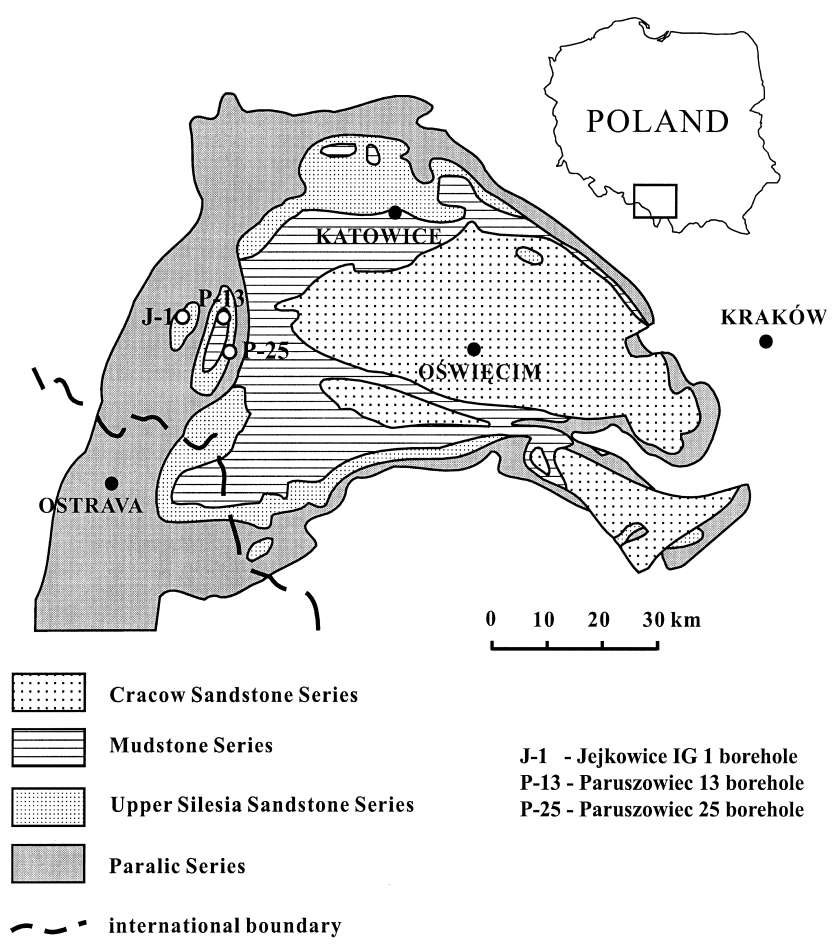

Fig. 1. Location of studied boreholes within the Upper Silesia Coal Basin. Position of study area within Poland is also shown. mudstone intercalations and sporadic thin coal beds. The Saddle Beds are typified by predominance of sandstones and conglomerates over siltstones and claystones and the presence of thick coal seams.

Gaebler (1891, fide Kotas \& Malczyk, 1972) recognized the presence of the four marine bands (Ia, Ib, Ic and Id in descending order) in the upper part of the Poruba Beds in the vicinity of Zabrze. These marine bands represent goniatite Eumorphoceras Zone $\left(\mathrm{E}_{2}\right)$, although the subzone $\mathrm{E}_{2 \mathrm{a}}$ has not been documented and subzones Cravenoceratoides nitidus $\left(\mathrm{E}_{2 \mathrm{~b}}\right)$ and Nuculoceras nuculum $\left(\mathrm{E}_{2 \mathrm{c}}\right)$ have not been subdivided because of lack of relevant data (Bojkowski, 1972). The marine bands of the Poruba Beds do not contain any Homoceras macrofauna (Bojkowski, 1972; Musiał et al., 1995) except one atypical specimen of Homoceras cf. striolatum in the uppermost marine band Ia (Hartung \& Patteisky, 1960). However, this has not been confirmed in later searches (Matl, 1965). In the vicinity of Rybnik the Poruba Beds are not complete; the uppermost

\begin{tabular}{|c|c|c|c|c|}
\hline \multicolumn{3}{|c|}{ Chronostratigraphy } & \multicolumn{2}{|c|}{ Lithostratigraphy } \\
\hline \multirow{4}{*}{ 鹿 } & \multirow{4}{*}{ 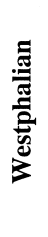 } & D & \multirow{2}{*}{$\begin{array}{l}\text { Cracow } \\
\text { Sandstone } \\
\text { Series }\end{array}$} & Libiąż Beds \\
\hline & & $\mathbf{C}$ & & Łaziska Beds \\
\hline & & B & \multirow{2}{*}{$\begin{array}{l}\text { Mudstone } \\
\text { Series }\end{array}$} & Orzesze Beds \\
\hline & & $\mathbf{A}$ & & Załęże Beds \\
\hline \multirow{7}{*}{ 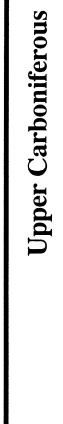 } & \multirow{7}{*}{ 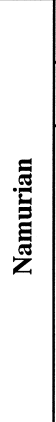 } & $\mathbf{C}$ & \multirow{3}{*}{$\begin{array}{l}\text { Upper Silesian } \\
\text { Sandstone } \\
\text { Series }\end{array}$} & Ruda Beds \\
\hline & & B & & Zabrze (Saddle) Beds \\
\hline & & \multirow{5}{*}{$\begin{array}{c}\mathbf{A} \\
\text { (part) }\end{array}$} & & Jejkowice Beds \\
\hline & & & \multirow{4}{*}{$\begin{array}{l}\text { Paralic } \\
\text { Series }\end{array}$} & Poruba Beds \\
\hline & & & & Jaklovec Beds \\
\hline & & & & Hrusov Beds \\
\hline & & & & Petrkovice Beds \\
\hline
\end{tabular}

Fig. 2. Lithostratigraphical division of the Upper Carboniferous deposits in the Upper Silesia Coal Basin (after Kotas, 1995). 


\section{PARUSZOWIEC 25}

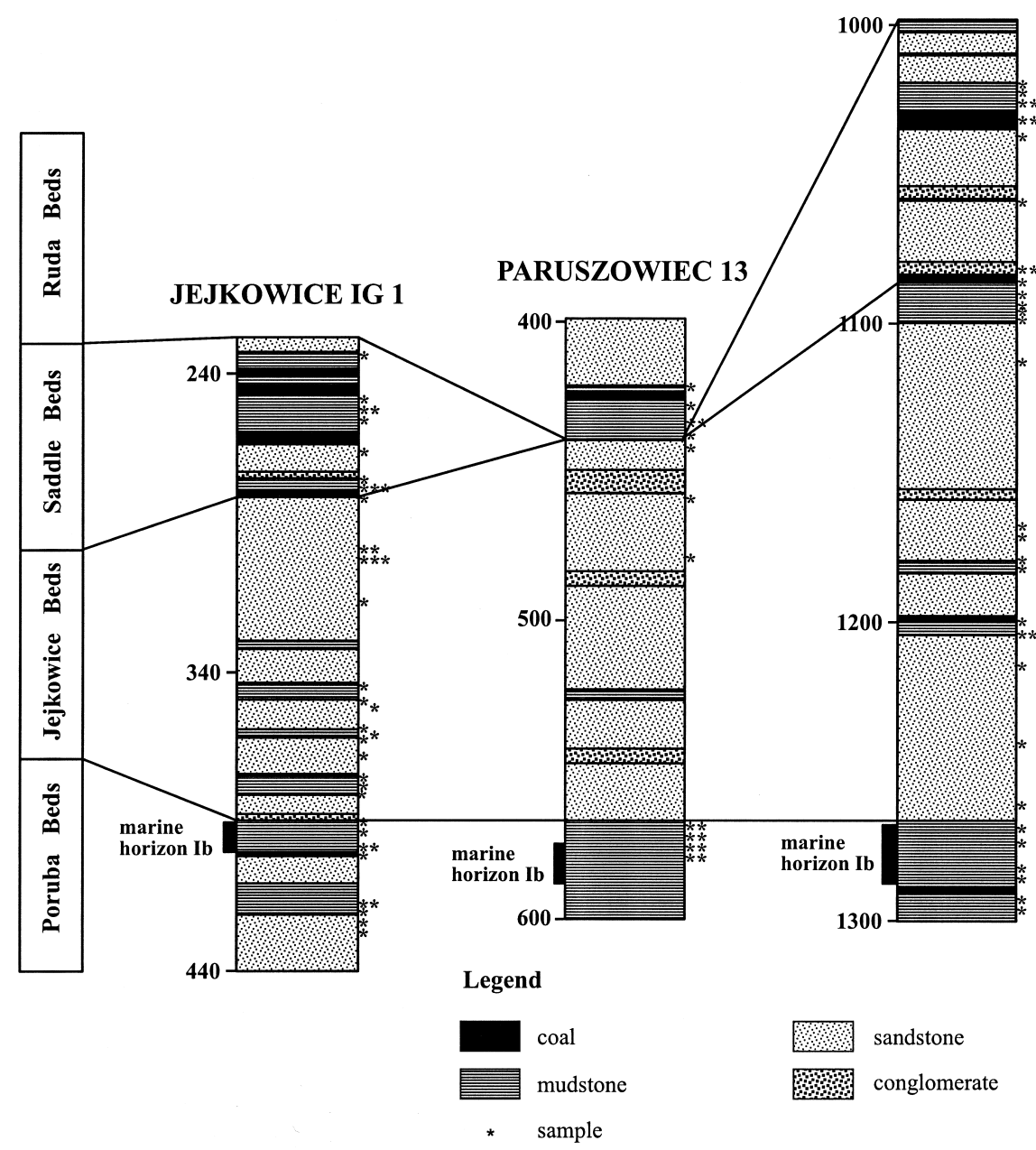

Fig. 3. Lithological profiles of studied boreholes and positions of the productive palynological samples.

marine band Ia, and even (in the Jejkowice trough) the succeeding marine band $\mathrm{Ib}$ are missing due to erosion (Matl, 1965, 1967, 1969, 1971).

\section{PREVIOUS BIOSTRATIGRAPHIC WORK}

The previous stratigraphical studies of this part of the coalbearing succession were carried out by several researchers. These studies focused on the macroflora (Kotasowa \& Migier, 1995), microflora (Jachowicz, 1972; Kmiecik, 1995), and macrofauna of the Poruba Beds (Matl, 1965, 1967, 1969, 1971; Bojkowski, 1972; Musiał et al., 1995). The age of the examined part of the coal-bearing succession is controversial, especially in case of the Jejkowice Beds. In the opinion of macroflorists (Kotasowa \& Migier, 1995) the Poruba and Jejkowice Beds represent the Arnsbergian stage, while the Saddle Beds contain floral assemblages indicative of the Kinderscoutian stage. Based on macrofloral studies, the Carboniferous sequence lacks the floral assemblages corresponding to Chokierian and Alportian stages. However, palynological studies of the Jejkowice Beds (Kmiecik, 1995) identified two local miospore zones that may be correlated with the west European miospore zones (Clayton et al., 1977) Kraeuselisporites ornatus-Lycospora subtriquetra (SO) and
Crassispora kosankei-Grumosisporites varioreticulatus (KV). The oldest local zone Ahrensisporites ornatus (Ao) appears to be a partial equivalent of the SO Zone of latest ArnsbergianAlportian age. The younger local zone Crassispora kosankei (Ck) corresponds to a part of the KV Zone of KinderscoutianMarsdenian age.

The present author distinguished three west European miospore zones in the Poruba, Jejkowice and Zabrze Beds in the studied boreholes. Figure 4 presents these zones with the ranges of the most stratigraphically useful miospores referred to in the paper.

The age determination of the examined part of the coalbearing succession and the explanation of the differences between the results of the macro- and microfloristic studies were among the objectives of the author's $\mathrm{PhD}$ dissertation. The present article is based on the taxonomic part of this work.

\section{SYSTEMATIC DESCRIPTIONS}

The described specimens are housed in the slide collection of the Institute of Geological Sciences, Polish Academy of Sciences, Research Centre in Kraków.

Anteturma Proximegerminantes (Sporites) H. Potonié 1893 
Miospores from the Namurian of Poland

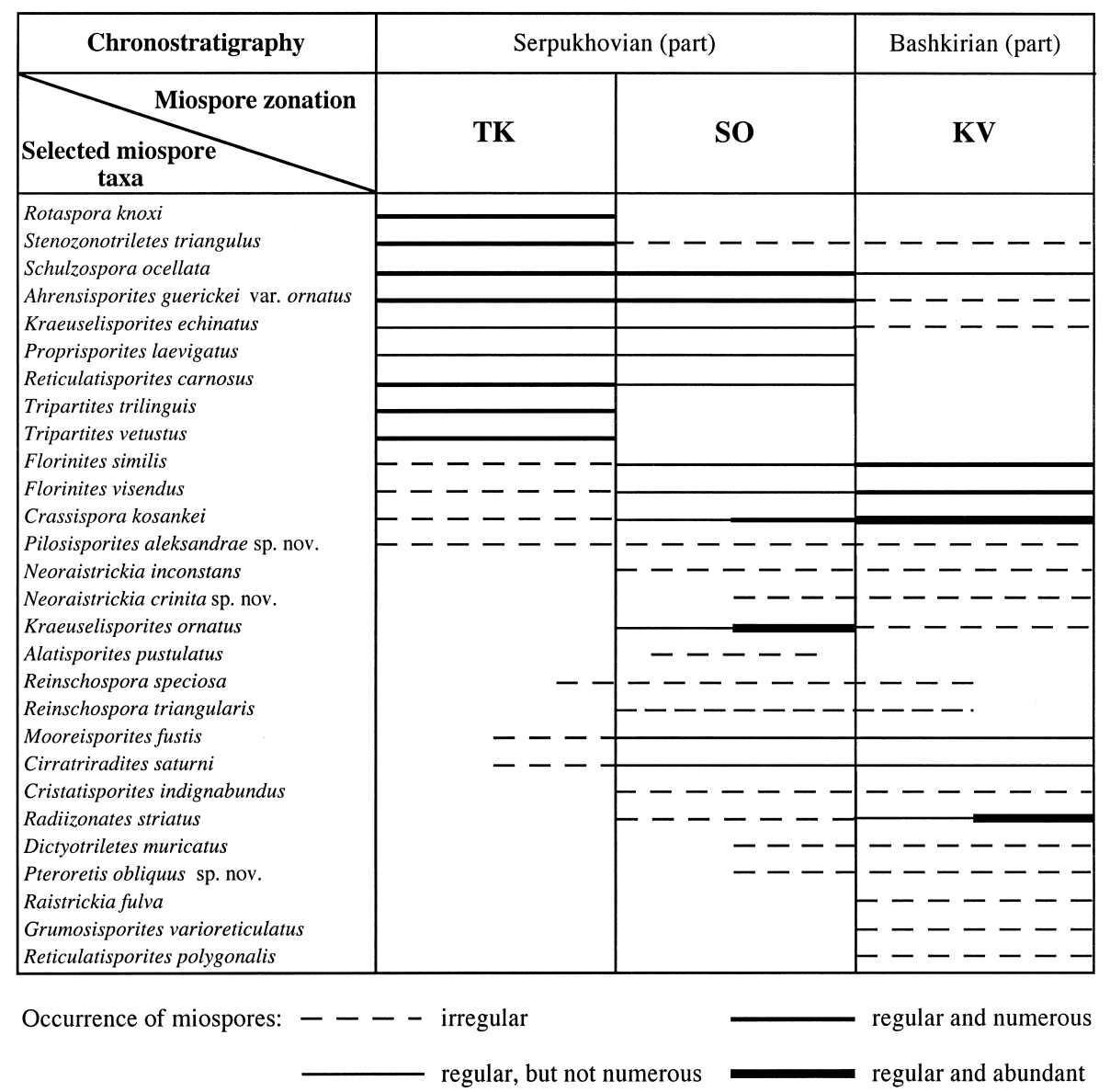

Fig. 4. Range chart of selected miospore species within miospore zones of Clayton et al. (1977).

Turma Triletes (Reinsch) Dettmann 1963 Suprasubturma Acavatitriletes Dettmann 1963 Subturma Azonotriletes (Luber) Dettmann 1963 Infraturma Apiculati (Bennie \& Kidston) Potonié \& Kremp 1954 Subinfraturma Baculati Dybova \& Jachowicz 1957 Genus Pilosisporites Delcourt \& Sprumont 1955

\section{Pilosisporites aleksandrae sp. nov.} (P1. 1, figs 1-9)

Type species. Pilosisporites trichopapillosus (Thiergart) Delcourt \& Sprumont 1955.

Diagnosis. Trilete miospores, amb almost circular to roundly subtriangular with convex sides. Trilete mark distinct, laesurae straight, reaching $4 / 5$ of the spore radius, occasionally extending to the spore margin. Exine of the contact area thin, laevigate. Outside of the contact area, exine densely sculptured with spinae, thin baculae or pila, which are also visible on the equator. The length of these elements is $0.5-2 \mu \mathrm{m}$, the width up to $0.5 \mu \mathrm{m}$. A circular, dark boss is situated at the distal polar region. Exine of the boss is laevigate, without ornamentation, its diameter is up to half of the spore diameter.

Holotype. P1. 1, figs 1-1*. Slide P13p3, England Finder reference J 41
Locality and horizon. Borehole Paruszowiec 13, depth 578.3579.3 m, Poruba Beds of Paralic Series.

Age. Arnsbergian.

Comparisons. The described species is smaller and more circular in shape than other species of this genus and possesses a characteristic boss. The upper Viséan Pilosisporites verutus Sullivan \& Marshall 1966 is larger $(40-50 \mu \mathrm{m})$ has a triangular $\mathrm{amb}$, straight or slightly concave sides, and rarely dispersed, longer $(3-8 \mu \mathrm{m})$ and thicker spinae (up to $3.5 \mu \mathrm{m}$ ). The upper Jurassic-lower Cretaceous Pilosisporites trichopapillosus (Thiergart) Delcourt \& Sprumont 1955 is much larger (50$85 \mu \mathrm{m}$ ), with ornamentation very similar to $P$. aleksandrae sp. nov. The Wealden Pilosisporites brevibaculatus Döring 1965 is very similar in size $(28-36 \mu \mathrm{m})$ and ornamentation, but the shape is more triangular with convex, rarely concave sides. The illustrated specimen of P. brevibaculatus (Döring 1965, pl. 11, figs 8-10) seems to posses a small boss at the distal polar region, but there is no mention about it in the description.

Dimensions. Equatorial diameter $26-36 \mu \mathrm{m}$ (based on 14 specimens). 

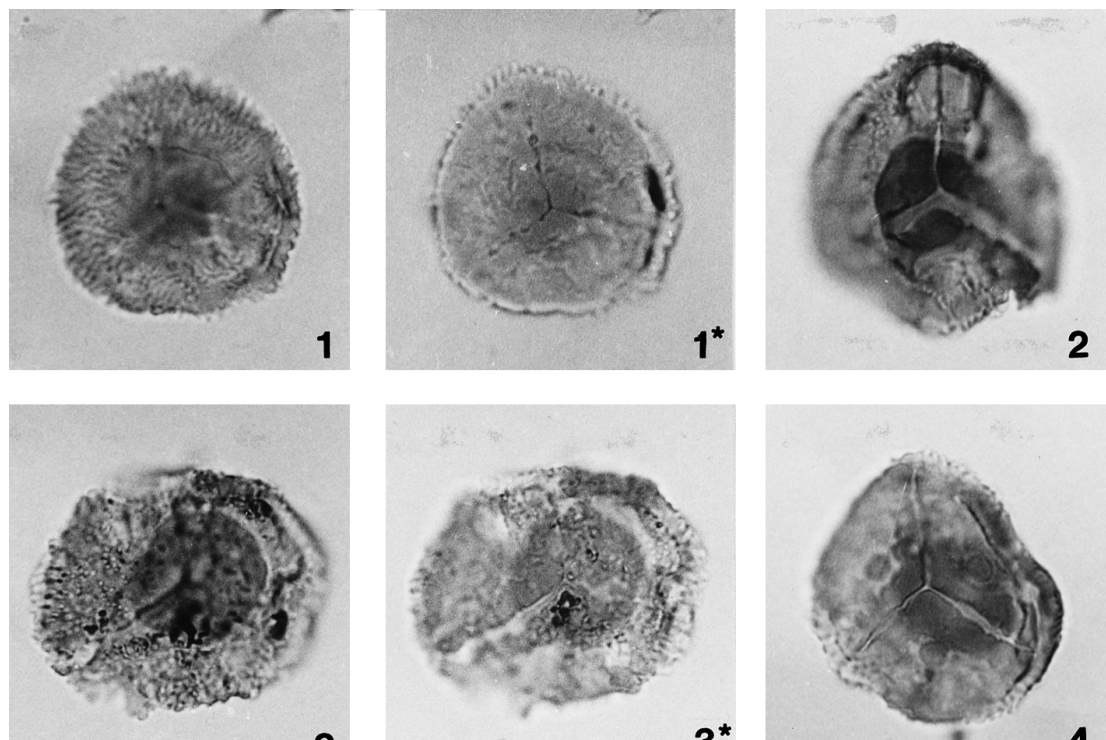

3
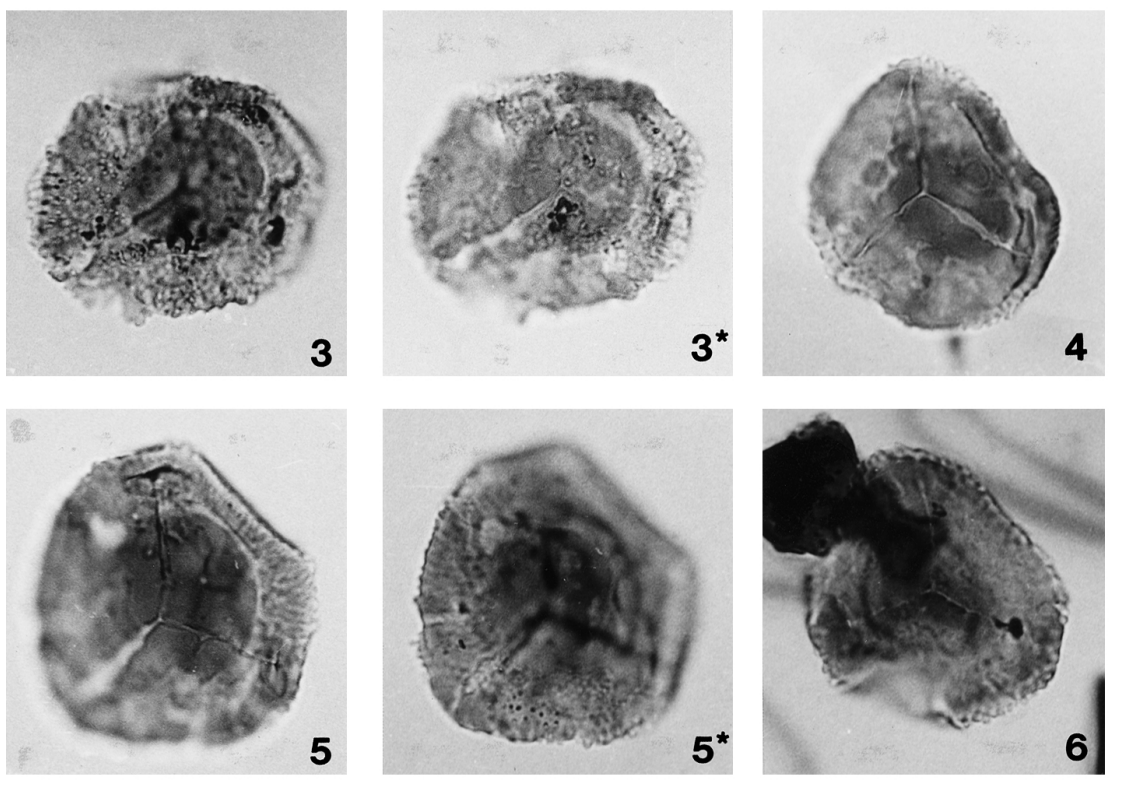
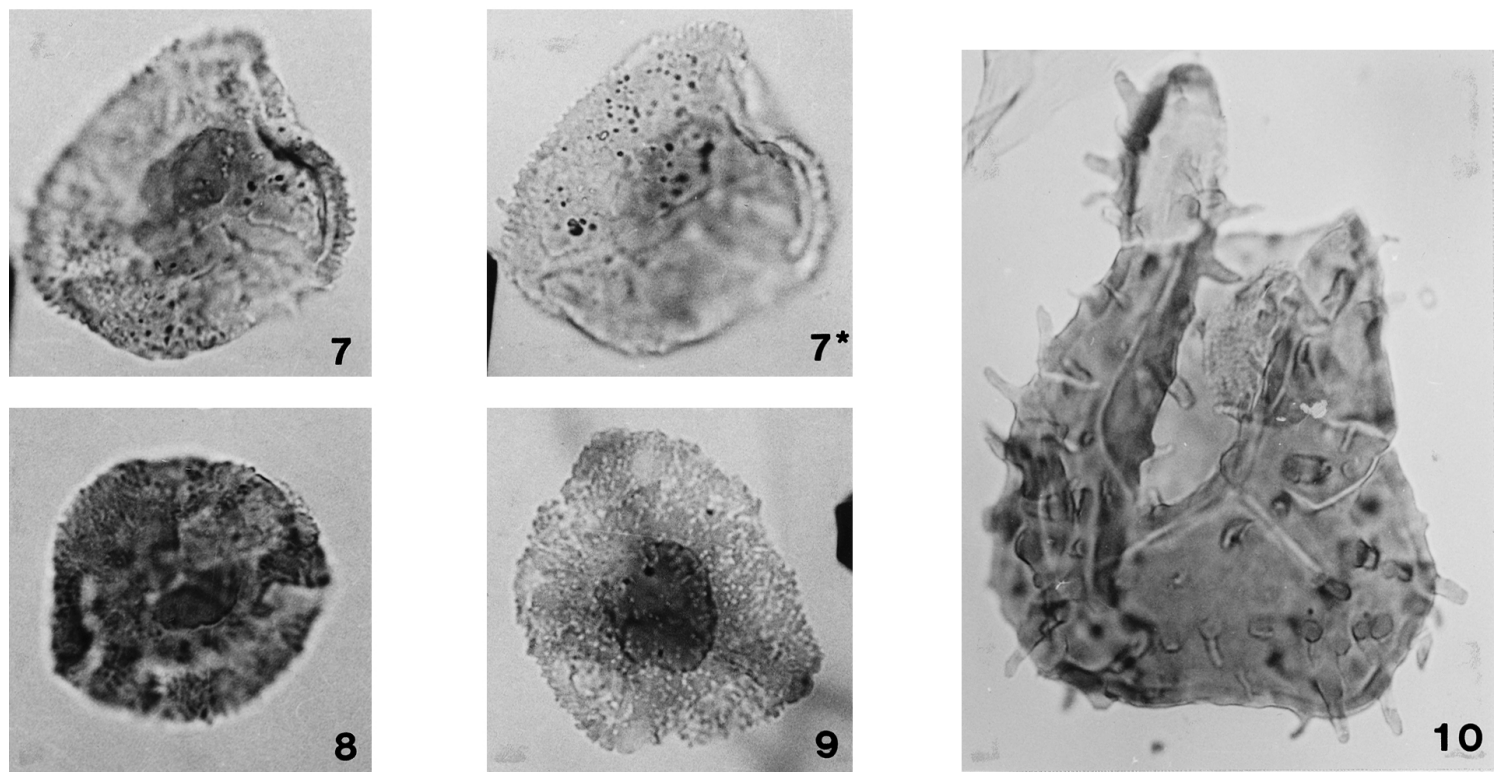

Explanation of Plate 1.

Figs 1-9. Specimens of Pilosisporites aleksandrae sp. nov., $\times 1000$ : 1-1*, holotype, Borehole Paruszowiec 13, depth interval 578.3- 579.3 m, slide P13p3, J 41 (1, distal view, 1*, proximal view); 2-3*, 7-7*, specimens from Paruszowiec 13 borehole, depth interval 566.5-567.5 m, slide P13p13 (2, $\mathrm{K} 48 / 4, \mathbf{3}, \mathrm{O} 32 / 3, \mathbf{7}, \mathrm{J} 43 / 2 ; \mathbf{2}-\mathbf{3}, \mathbf{7}$, proximal view, $\mathbf{2}^{*} \mathbf{3}^{*}, \mathbf{7}^{*}$, distal view); 4-5*, specimens from Paruszowiec 25 borehole, depth $1262.05 \mathrm{~m}$, slide P25j1 (4, S 42/2, 5, J 35; 5, 6, proximal view, $\mathbf{5}^{*}, \mathbf{6}^{*}$, distal view); 8, specimen from Paruszowiec 25 borehole, depth interval 1022.3-1023.2 m, slide P25s10, E 50/3; 9, poorly preserved specimen from Paruszowiec 13 borehole, depth interval 577.3-578.3 m, slide P13p4, M 42/1. Fig. 10. Specimen of Neoraistrickia crinita sp. nov., × 600, Borehole Jejkowice IG 1, depth interval 370.9-376.4 m, slide M16, G25/2. Co-ordinates for all figures are for England Finder. 
Stratigraphic distribution. Concurrent range zones TK, SO, KV; Upper Carboniferous, Arnsbergian-Marsdenian, but the range may possibly be wider.

Remarks. Playford (1986) described a miospore genus, Rattiganispora, from the Australian Carboniferous, with two species: $R$. apiculata and $R$. acuminata. The size, shape and sculptural projections of the first of these species are very similar to those of Pilosisporites aleksandrae, but the genus Rattiganispora has a more complicated construction of the distal surface. Rattiganispora possesses (1) an ornamented outer ring, (2) an unsculptured medial, moat-like area, more or less depressed, and (3) an ornamented boss-like area, centred at or near the distal pole. On the contrary, $P$. aleksandrae possesses (1) an azonate, ornamented exine and (2) an unsculptured boss. The differences in morphology and ornamentation between $R$. apiculata and $P$. aleksandrae establish the basis for the assignment of the new described species to the genus Pilosisporites. In the opinion of the present author, the occurrence of the boss on the distal surface of the described species is not a sufficient reason for the establishment of the new genus. For example, the occurrence of the boss in Diatomozonotriletes ubertus has not been the basis for the creation of a new genus, but has been recognized as an important feature in the species description.

\section{Genus Neoraistrickia Potonié 1956 \\ Neoraistrickia crinita $\mathrm{sp}$. nov. \\ (Pl. 1, fig.10; Pl. 2, figs 1-3)}

Type species. Neoraistrickia truncatus (Cookson) Potonié 1956

Diagnosis. Trilete miospores, amb triangular with concave to straight sides. Trilete mark with laesurae $1 / 2$ to $2 / 3$ of spore radius in length; sutures often open. Exine of contact area is laevigate. Outside of the contact area, the exine is sculptured with long and rather thin (up to $2.5 \mu \mathrm{m}$ ) baculae and spinae, $7.5-10 \mu \mathrm{m}$ in length. The ornamentation of the radial areas is denser than that of the inter-radial areas, which sometimes lack baculae and spinae.

Holotype. Plate 2, figure 1. Slide P25j3, England Finder reference M50/2.

Locality and horizon. Borehole Paruszowiec 25, depth $1216.2 \mathrm{~m}$, Jejkowice Beds of the Upper Silesia Sandstone Series.

Age. Kinderscoutian.

Comparisons. The described species is much larger and possesses longer and thinner baculae than other species of the genus Neoraistrickia. The upper Viséan Neoraistrickia drybrookensis Sullivan 1964 is smaller $(33-50 \mu \mathrm{m})$ and ornamented with cones (up to $3 \mu \mathrm{m}$ high and wide), verrucae (up to $15 \mu \mathrm{m}$ in their longest diameter and $7 \mu \mathrm{m}$ high), and baculae (up to $8 \mu \mathrm{m}$ high and $6 \mu \mathrm{m}$ wide). The Namurian Neoraistrickia inconstans Neves 1961 is smaller $(55-75 \mu \mathrm{m})$ and ornamented with shorter and thicker baculae (3-8 $\mu \mathrm{m}$ high and $2-4 \mu \mathrm{m}$ wide) than $N$. crinita sp. nov.
Dimensions. Equatorial diameter 77.5 (91) to $125 \mu \mathrm{m}$ (based on 10 specimens).

Stratigraphic distribution. Concurrent range zones SO, KV; Upper Carboniferous, latest Arnsbergian-Marsdenian, but further studies may extend this range to younger zones.

\section{Incertae Sedis}

\author{
Genus Pteroretis Felix \& Burbridge 1961 \\ Pteroretis obliquus sp. nov. \\ (Pl. 2, figs 4-8; Pl. 3, figs 1-3)
}

Type species. Pteroretis primum Felix \& Burbridge 1961

Diagnosis. Spores of oval amb, usually obliquely compressed. Tetrad mark not distinguishable. Spore body included within the outer perisporal membrane, which bears four to five muri, here described as wings that encircle the spore body running more or less parallel to each other and, presumably, to the equatorial axis. The wings are composed of ribs bearing crests. The ribs are 5-7.5 $\mu \mathrm{m}$ wide at base and $10-17.5 \mu \mathrm{m}$ apart. The crests are membranous, veined perpendicular to their length, $7.5-12.5 \mu \mathrm{m}$ in height. Thinner ribs intersect the spaces between wings, reaching them slightly obliquely. They are about $1 \mu \mathrm{m}$ in width and 5-7.5 $\mu \mathrm{m}$ apart. The wings are often poorly preserved because of their very delicate structure, in such cases the spores look like specimens illustrated in Plate 2, figures 5-6.

Holotype. Plate 2, figure 7. Slide M13, England Finder reference C35/C36.

Locality and horizon. Borehole Jejkowice IG 1, depth 344.2$348.5 \mathrm{~m}$, Jejkowice Beds of the Upper Silesia Sandstone Series.

\section{Age. Chokierian-Alportian.}

Dimensions. Equatorial diameter 70 (90.5) to $117.5 \mu \mathrm{m}$ (based on 10 specimens), the spore body measures from $60 \mu \mathrm{m}$ to $97.5 \mu \mathrm{m}$ in diameter (based on 6 undistorted specimens).

Stratigraphic distribution. Concurrent range zones SO, KV; Upper Carboniferous, ?Chokierian-Marsdenian, but the range may possibly be wider.

Remarks. Pteroretis obliquus sp. nov. represents an unusually ornamented spore type whose morphology is difficult to interpret. The occurrence of characteristic ornamentation (muri represented by ribs with fixed diaphanous crests) closely resembles Pteroretis primum Felix \& Burbridge 1961, and to spores of the Palaeozoic sphenophyllalean cone Bowmanites dawsoni, described by Taylor (1970). However, P. primum as well as $B$. dawsoni spores possess higher wings (up to $32-35 \mu \mathrm{m}$ when the wings are fully expanded), which, moreover, are discontinuous in the Bowmanites spores, and running meridionally in Pteroretis primum. Felix \& Burbridge (1961) supposed that the outer, ornamented membrane in P. primum represented 

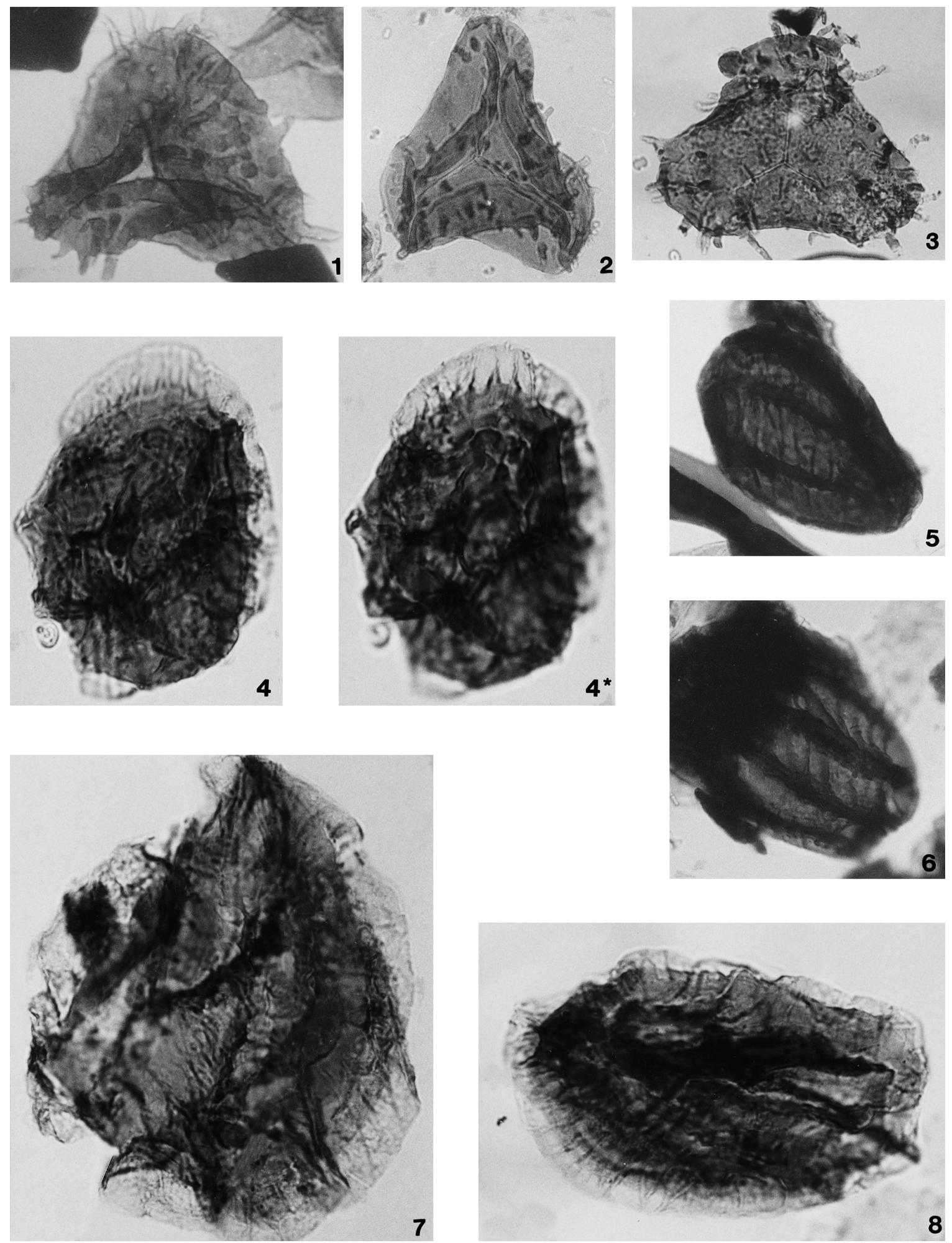

Explanation of Plate 2.

Figs 1-3. Specimens of Neoraistrickia crinita sp. nov., × 500: 1, holotype, Borehole Paruszowiec 25, depth 1216.2 m, slide P25j3, M 50/2; 2, specimen from Jejkowice IG 1 borehole, depth interval 370.9-376.4 m, slide J1j3, R 36; 3, specimen from Jejkowice IG 1 borehole, depth 348.5 m, slide M12, S 42/1. Figs 4, 7-8. Specimens of Pteroretis obliquus sp. nov., $\times 1000$ : 4 4*, specimen from Jejkowice IG 1 borehole, depth interval $344.2-348.5 \mathrm{~m}$, slide NM13/2, F 36/2; 7, holotype, Borehole Jejkowice IG 1, depth interval 344.2-348.5 m, slide M13, C 35/C 36; 8, specimen from Jejkowice IG 1 borehole, depth interval 344.2-348.5 m, slide NM13/1, H 46/1. Figs 5-6. Broken specimens of P. obliquus sp. nov., $\times 500$, from Jejkowice IG 1 borehole, depth $368.6 \mathrm{~m}$, slide J1j4 (5, K 46, 6, U 43/U 44). Co-ordinates for all figures are for England Finder. 
Miospores from the Namurian of Poland
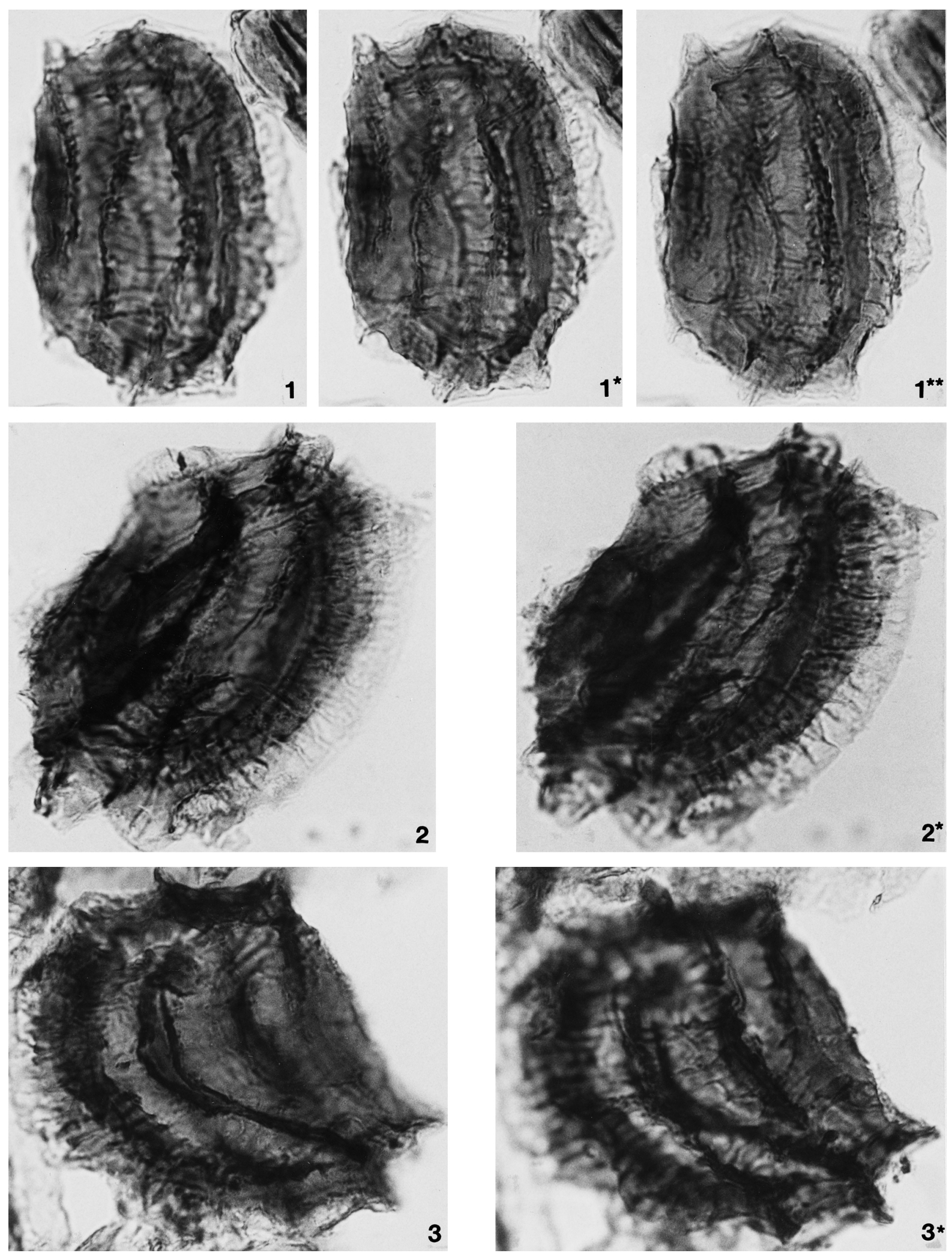

Explanation of Plate 3.

Figs 1-3. Specimens of Pteroretis obliquus sp. nov., × 1000: 1-1**, slide NM13/2, P 40; 2-2*, slide M13, J 38/1; 3-3*, slide M13, H 45. All specimens from Jejkowice IG 1 borehole, depth interval 344.2-348.5 m. Co-ordinates are for England Finder. 
perispore, and that the tetrad mark was present beneath this membrane. Taylor (1970) illustrated a broken specimen of Bowmanites spores showing the tetrad mark in the opening in the outer membrane. The present material is too poor in specimens to allow study of broken ones under SEM but a similar structure as that in $P$. primum and $B$. dawsoni spores may be presumed.

The occurrence of spores resembling the described species has not been mentioned frequently in the Carboniferous palynological literature. Ettensohn \& Peppers (1979, pl. 2, fig. 23) included an illustration of a specimen found in the deposits of the Pennington Formation of the middle and late Chesterian age, which resembles Pteroretis obliquus. They classified this specimen as Pteroretis primum Felix \& Burbridge 1961 and suggested it is the same as Incertae Sedis in Hoffmeister et al. (1955). In the opinion of the present author, the description (p. 398) and illustration (pl. 39, fig. 9) included in Hoffmeister et al. (1955) suggest that their Incertae Sedis is Pteroretis primum with destroyed wings. Unfortunately, Ettensohn \& Peppers (1979) did not provide any description of the above-mentioned species. However, their specimen appears closer to $P$. obliquus than P. primum.

\section{STRATIGRAPHICAL DISTRIBUTION}

Pilosisporites aleksandrae first appears in the miospore assemblages containing Rotaspora knoxi, Stenozonotriletes triangulus and other characteristic species (Fig. 4), like Schulzospora ocellata, Ahrensisporites guerickei var. ornatus, Kraeuselisporites echinatus, Proprisporites laevigatus, Reticulatisporites carnosus, Tripartites trilinguis, T. vetustus and, in marine bands, Florinites similis and Florinites visendus. The occurrence of the two first mentioned species allows assignment of the described assemblages to the Stenozonotriletes triangulus-Rotaspora knoxi Zone (TK) of Arnsbergian age.

Neoraistrickia crinita first appears slightly later, in the latest Arnsbergian, in the assemblages representing the Lycospora subtriquetra-Kraeuselisporites ornatus Zone (SO). This is based upon the occurrence in assemblages of such important miospore species as Kraeuselisporites ornatus, Alatisporites pustulatus, Reinschospora speciosa, $R$. triangularis and Mooreisporites fustis. It is interesting that the miospore assemblages from the marine band Ib in the Poruba Beds in the Jejkowice IG 1 borehole (see Fig. 3) resemble the ones described by Neves (1961) from the Namurian deposits in the Southern Pennines. These very well preserved and taxonomically diversified assemblages contain such species as Dictyotriletes karadenisensis, D. tuberosus, Convolutispora obliqua, Neoraistrickia inconstans, Rugospora corporata, R. minuta, Secarisporites remotus, Spinozonotriletes tuberculatus and Tholisporites? bianulatus.

The first appearance of Pteroretis obliquus is in the Chokierian or the Alportian, in assemblages corresponding to the upper part of the SO Zone. This assignment is based on the regular and numerous occurrence of Kraeuselisporites ornatus (up to 12\%) and progressive incoming of species which are characteristic of the late Namurian (Crassispora kosankei, Cirratriradites saturni, Cristatisporites indignabundus, Radiizonates striatus, Dictyotriletes muricatus and Laevigatosporites vulgaris).

In the examined boreholes all new species have their last appearance in the middle Namurian, in the deposits representing the Crassispora kosankei-Grumosisporites varioreticulatus Zone $(\mathrm{KV})$. This is based upon the abundant occurrence of Crassispora kosankei (about 13\%) and appearance in miospore assemblages of such species as Raistrickia fulva, Grumosisporites varioreticulatus, Reticulatisporites polygonalis and Retispora staplini. In the Paruszowiec 13 borehole where the Saddle Beds are missing and the Jejkowice Beds are overlain by the Ruda Beds, the miospore assemblages of the latter represent the Triquitrites sinani-Cirratriradites saturni Zone (SS) of the Langsettian age. These assemblages did not contain any new described species, so the conclusion is that in the study area these species are stratigraphically restricted to the Namurian. The described species occur rarely in miospore assemblages, suggesting that their parent plants were only a minor component of the Carboniferous flora.

\section{ACKNOWLEDGEMENTS}

The author thanks Professor Elżbieta Turnau (Institute of Geological Sciences, Polish Academy of Sciences) for constructive comments on the manuscript. Thanks are also due to Dr Kenneth Higgs and an anonymous reviewer for their valuable comments, which improved this article.

\section{Manuscript received 15 October 2000 \\ Manuscript accepted 10 July 2001}

\section{REFERENCES}

Bojkowski, K. 1972. A description of the Upper Carboniferous Fauna of the Upper Silesian Coal Basin. Prace Inst. Geol., 61: 89-134 (in Polish, English summary).

Clayton, G., Coquel, R., Doubinger, J., Gueinn, K. J., Loboziak, S., Owens, B. \& Streel, M. 1977. Carboniferous miospores of western Europe - illustration and zonation. Meded. Rijks Geolog. Dienst, 29: $1-72$.

Delcourt, A. \& Sprumont, G. 1955. Curieuse association de microfossiles dans le Wéaldien de Féron-Glageon, France. Bulletin Societe Belge Géol. Paleont. Hydrol., 68: 122-125.

Dettmann, M. 1963. Upper Mesozoic microfloras from southeastern Australia. Proceedings of the Royal Society of Victoria, 77: $1-148$.

Dybova, S. \& Jachowicz, A. 1957. Microspores of the Upper Silesian Coal Measures. Prace Inst. Geol., 23: 1-326 (in Polish, English summary).

Döring, H. 1965. Die sporenpaläontologische Gliederung des Wealden in Westmecklenburg (Struktur Werle). Geologie, Beih., 47: 1-117.

Ettensohn, F. R. \& Peppers, R. A. 1979. Palynology and biostratigraphy of Pennington shales and coals (Chesterian) at selected sites in northeastern Kentucky. Journal of Paleontology, 53: 453-474.

Felix, C. J. \& Burbridge, P. P. 1961. Pteroretis, a new Mississipian spore genus. Micropaleontology, 7: 491-495.

Hartung, W. \& Patteisky, K. 1960. Die Flora der Goniatiten-Zonen im Visé und Namur des ostsudetischen Karbons. Comtes rendus IV Cong. Avanc. Strat. Geol. Carbonifere, Heerlen, 1: 247-261.

Hoffmeister, W. S., Staplin, F. L. \& Malloy, R. E. 1955. Mississipian plant spores from the Hardinsburg Formation of Illinois and Kentucky. Journal of Paleontology, 29: 372-399.

Jachowicz, A. 1972. A microfloristic description and stratigraphy of the productive Carboniferous of the Upper Silesian Coal Basin. Prace Inst. Geol., 61: 185-277 (in Polish, English summary).

Kmiecik, H. 1995. Microflora. The Carboniferous system in Poland. Prace Pañstw. Inst. Geol., 148: 70-85.

Kotas, A. \& Malczyk, W. 1972. The Paralic Series of the Lower Namurian stage of the Upper Silesian Coal Basin. Prace Inst. Geol., 61: $329-425$.

Kotas, A. 1995. Upper Silesian Coal Basin. The Carboniferous system in Poland. Prace Pañstw. Inst. Geol., 148: 124-134. 
Miospores from the Namurian of Poland

Kotasowa, A. \& Migier, T. 1995. Macroflora. The Carboniferous system in Poland. Prace Pañstw. Inst. Geol., 148: 56-65.

Matl, K. 1965. Position stratigraphique des deux niveaux marins les plus supérieurs des couches marginales (Namurien A) de la région de Rybnik. Ann. Soc. Geol. Pol., 35: $443-466$ (in Polish, French summary).

Matl, K. 1967. La lacune d'érosion dans la partie supérieure des couches marginales dans la Région Houillere de Rybnik (Haute Silésie). Ann. Soc. Geol. Pol., 37: 109-118 (in Polish, French summary).

Matl, K. 1969. The stratigraphy of the upper marginal beds (Upper Namurian A) in the Rybnik Coal District (Upper Silesian Coal Basin). Geological Transactions, 58: 5-88 (in Polish, English summary).

Matl, K. 1971. Faunal horizons in the Poruba and Jaklovec beds (Upper Namurian A) of the western part of the Upper Silesian Coal Basin (Poland). Geological Transactions, 67: 5-105 (in Polish, English summary).

Musiał, Ł., Tabor, M. \& Żakowa, H. 1995. Macrofauna. The Carboniferous system in Poland. Prace Pañstw. Inst. Geol., 148: 23-44.
Neves, R. 1961. Namurian plant spores from the southern Pennines, England. Palaeontology, 4: 247-279.

Playford, G. 1986. Morphological and preservational variation of Rattiganispora Playford and Helby, 1986, from the Australian Carboniferous. Pollen et Spores, 28: 83-96.

Potonié, R. 1956. Synopsis der Gattungen der Sporae dispersae I. Beih. Geologisches Jahrbuch, 23: 1-103.

Potonié, R. \& Kremp, G. 1954. Die Gattungen der paläozoischen Sporae dispersae und ihre Stratigraphie. Geologisches Jahrbuch, 69: 78-149.

Sullivan, H. J. 1964. Miospores from the Drybrook Sandstone and associated measures in the Forest of Dean Basin, Gloucestershire. Palaeontology, 7: 351-392.

Sullivan, H. J. \& Marshall, A. E. 1966. Viséan spores from Scotland. Micropaleontology, 12: 265-285.

Taylor, T. N. 1970. The morphology of Bowmanites dawsoni spores. Micropaleontology, 16: 243-248. 